\title{
Real time in situ detection of organic nitrates in atmospheric aerosols
}

\author{
Andrew W. Rollins, ${ }^{\dagger}$ Jared D. Smith, ${ }^{\ddagger}$ Kevin R. Wilson, ${ }^{\ddagger}$ and Ronald C. Cohen ${ }^{*, \dagger}, \mathbb{\pi}$ \\ Department of Chemistry, University of California, Berkeley, Chemical Sciences Division, \\ Lawrence Berkeley National Laboratory, and Department of Earth and Planetary Science, \\ University of California, Berkeley \\ E-mail: rccohen@berkeley.edu
}

\begin{abstract}
A novel instrument is described that quantifies total particle phase organic nitrates in real time with a detection limit of $0.11 \mu \mathrm{g} \mathrm{m}^{-3} \mathrm{~min}^{-1}, 45 \mathrm{ppt} \min ^{-1}\left(-\mathrm{ONO}_{2}\right)$. Aerosol nitrates are separated from gas phase nitrates with a short residence time activated carbon denuder. Detection of organic molecules containing $-\mathrm{ONO}_{2}$ subunits is accomplished using thermal dissociation coupled to laser induced fluorescence detection of $\mathrm{NO}_{2}$. This instrument is capable of high time resolution (seconds) measurements of particle phase organic nitrates, without interference from inorganic nitrate. Here we use it to quantify organic nitrates in secondary organic aerosol generated from high- $\mathrm{NO}_{\mathrm{x}}$ photooxidation of limonene, $\alpha$-pinene, $\Delta$-3-carene, and tridecane. In these experiments the organic nitrate moiety is observed to be $6-15 \%$ of the total SOA mass.
\end{abstract}

\footnotetext{
${ }^{*}$ To whom correspondence should be addressed

${ }^{\dagger}$ Department of Chemistry, University of California, Berkeley

${ }^{\ddagger}$ Chemical Sciences Division, Lawrence Berkeley National Laboratory

IDepartment of Earth and Planetary Science, University of California, Berkeley
} 


\section{Introduction}

Organic nitrates $\left(\mathrm{RONO}_{2}\right)$ are formed in the atmosphere as a minor product of reactions between organic peroxy radicals and nitric oxide (NO), as well as a major product from reactions of alkenes with the nitrate radical $\left(\mathrm{NO}_{3}\right)$. As a result, $\mathrm{RONO}_{2}$ molecules are chemically produced during the day and the night and are a significant fraction of the total oxidized nitrogen $\left(\mathrm{NO}_{\mathrm{y}}\right)$ anywhere that non-methane organic compounds are available (e.g. (1)). Specific individual gas phase $\mathrm{RONO}_{2}$ molecules have been observed using gas chromatography (e.g. (2-6)) and chemical ionization mass spectrometry (7-9), and the total of gas and aerosol $\mathrm{RONO}_{2}$ (total Alkyl Nitrates, $\Sigma \mathrm{AN}$ ) has been observed by Thermal Dissociation Laser Induced Fluorescence (TD-LIF) (1, 10-12). Recently there has been growing interest in understanding the partitioning of $\mathrm{RONO}_{2}$ to atmospheric particles (13-18). $\mathrm{RONO}_{2}$ molecules with 2 - 4 functional groups and a carbon backbone of $\geq \mathrm{C}_{4}$ have low enough vapor pressures to condense under ambient conditions and mechanistic studies show that $\mathrm{RONO}_{2}$ can be among the most important molecules to SOA formation (e.g. $\left.(13,19)\right)$.

Despite the theoretical and laboratory evidence that $\mathrm{RONO}_{2}$ should be important to the composition of atmospheric organic aerosols, there remains little evidence that $\mathrm{RONO}_{2}$ are widespread components of ambient SOA. The most compelling evidence derives from direct FTIR analysis of particles impacted on $\mathrm{ZnSe}$ plates. This technique has been used to identify organic nitrates as ubiquitous components of submicron particles sampled in the Los Angeles basin $(20,21)$ and in Houston (22). FTIR analysis provides quantitative measurements of positively identified organic functionalities, with time resolution limited to the rate at which filters are changed (typically hours - days). Interferences due to evaporative loss from the filters or heterogeneous reactions on the filters during sampling are known issues and difficult to quantify. Individual large multifunctional nitrates have been observed in ambient aerosol samples collected on filters using electrospray ionization mass spectrometry $(23,24)$. However the most widely used methods for aerosol chemical characterization including Aerosol Mass Spectrometry (AMS) have had limited success. The difficulty of distinguishing inorganic and organic nitrates using AMS has been recently discussed in the literature (16-18). Nitrates have not yet been reported by Thermal Desorption Aerosol Gas- 
Chromatography (TAG) (25) or other methods of detailed realtime aerosol characterization.

In this paper a new technique for the detection of aerosol organic nitrate is described. The new method quantifies particulate organic nitrate with high time resolution, low background signal, and no interference from inorganic nitrate ion $\left(\mathrm{NO}_{3}^{-}\right)$. Here we apply the method to measure the organic nitrate content of SOA produced in the laboratory from high $\mathrm{NO}_{\mathrm{x}}$ photooxidation of one alkane and three alkenes. In these experiments, we show that the fraction of the total organic mass which is organic nitrate is consistent with the expected organic nitrate yields from high $\mathrm{NO}_{\mathrm{x}}$ photooxidation.

\section{Instrument Design and Evaluation}

The selective measurement of particle phase nitrates is achieved by removing gas phase $\mathrm{NO}_{2}$ and nitrates (both $\mathrm{RO}_{2} \mathrm{NO}_{2}$ and $\mathrm{RONO}_{2}$ ) from the sample stream with an activated carbon denuder. The aerosol flow is then heated so that particles are vaporized to their gas phase precursors and detected using TD-LIF by which $\mathrm{RONO}_{2}$ is thermally converted to $\mathrm{RO}+\mathrm{NO}_{2}$ and $\mathrm{NO}_{2}$ is detected by LIF (10). A schematic of the instrument inlet system used in this study is shown in Figure 1.

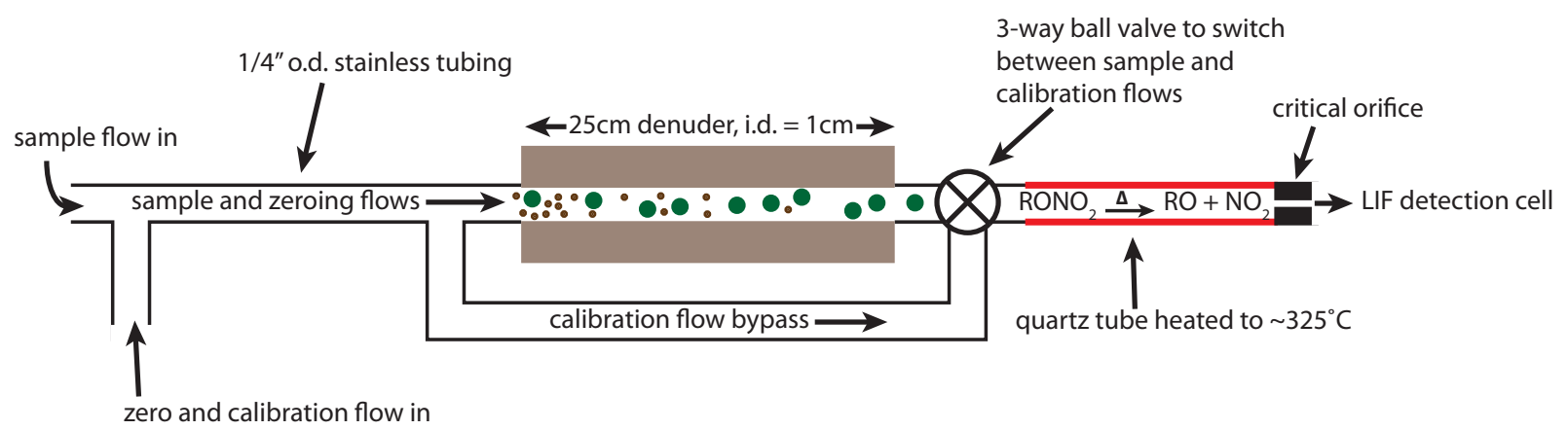

Figure 1: Schematic of particle organic nitrate inlet system. Gas and particles are sampled through $\approx 10 \mathrm{~cm}$ of 0.25 " o.d. stainless tube. The flow enters the denuder where particles (green dots) pass while gas phase $\mathrm{NO}_{\mathrm{y}}$ (brown dots) is removed by uptake on the denuder walls. Organic nitrate particles are converted to $\mathrm{NO}_{2}$ in a heated quartz tube. A critical orifice reduces the pressure to $\approx 2$ torr for measurement by LIF. 


\section{Thermal Dissociation Laser Induced Fluorescence}

The core measurement used in TD-LIF is the laser induced fluorescence detection of $\mathrm{NO}_{2}(26)$. Details of the specific LIF instrument used for this study are described in Wooldridge et al. (27). Briefly, gas is sampled through a critical orifice into a 38 pass White cell held at $\approx 2$ torr. $\mathrm{NO}_{2}$ is excited with a $30 \mathrm{~mW}$ diode laser centered at $408 \mathrm{~nm}$ (Power Technologies Inc.). Red shifted $\mathrm{NO}_{2}$ fluorescence passes through a $650 \mathrm{~nm}$ long pass dielectric filter and a red glass filter which block scatter and is detected with a photomultiplier tube (Hamamatsu H7421-50). Alkyl nitrates and nitric acid $\left(\mathrm{HNO}_{3}\right)$ are quantified by sampling through a heated inlet which thermally dissociates these molecules to $\mathrm{NO}_{2}$ and a corresponding radical. The method has been compared to independent approaches for detection of $\mathrm{NO}_{2}(28,29)$, total peroxy nitrates $(\Sigma \mathrm{PN})(27)$ and $\Sigma \mathrm{AN}$ (9). In this work we used an inlet which consisted of a $4 \mathrm{~mm}$ i.d. quartz tube wrapped in nichrome wire providing a heated length of $20 \mathrm{~cm}$. Using a flow rate of $125 \mathrm{sccm}$ the residence time in the heated region was $1.2 \mathrm{~s}$. The setpoint used to thermally dissociate all organic nitrates, while rejecting $\mathrm{HNO}_{3}$ was determined by scanning the inlet temperature while sampling a mixture of ethyl nitrate and $\mathrm{HNO}_{3}$ (Figure 2).

TD-LIF has previously been used to quantify various classes of gas + particle $\mathrm{NO}_{\mathrm{y}}$ by taking the difference in LIF signals measured with two inlets at two different temperatures (10). For the application described in this work, gas phase species including $\mathrm{NO}_{2}$ are separated from particles before entering the heated portion of the inlet, and thus no subtraction is required.

\section{Gas/Particle Separation}

Gas phase $\mathrm{NO}_{\mathrm{y}}$ is removed using a single channel cylindrical denuder, $25 \mathrm{~cm}$ in length, and 1.0 $\mathrm{cm}$ i.d., which provides $9.3 \mathrm{~s}$ residence time at a flow rate of $125 \mathrm{sccm}$. We tested the effectiveness of the denuder for removing $\mathrm{NO}_{2}$ and organic nitrates by using an injector inside the denuder in a concentric flow tube configuration. We measured the penetration of $\mathrm{NO}_{2}$ and n-propyl nitrate (NPN) as a function of length of denuder exposed and gas flow rate. The data were compared to the predicted penetration as calculated by the expression obtained by Ingham et al.(30) (equations 


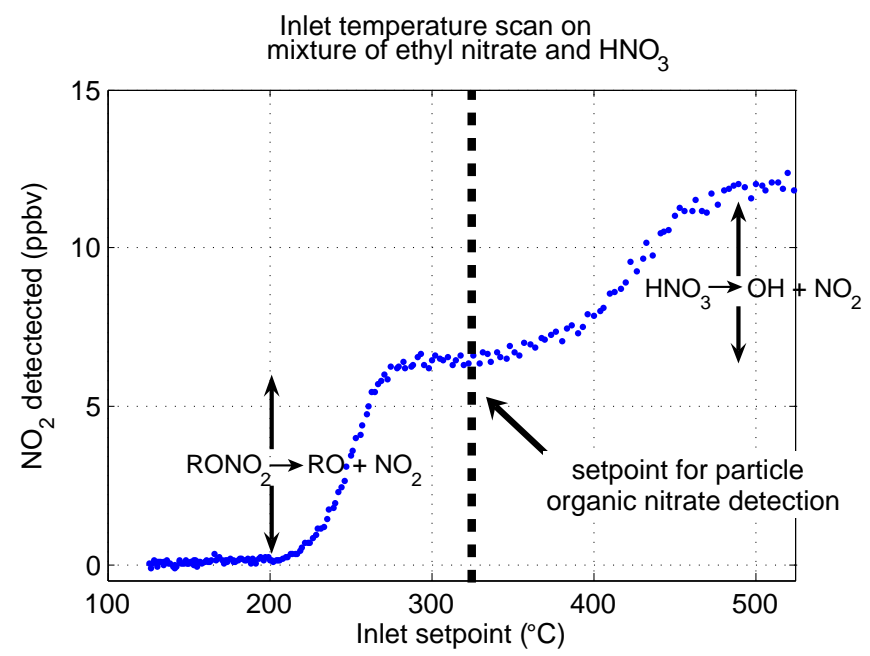

Figure 2: Inlet temperature scan on a mixture of gas phase n-propyl nitrate and nitric acid.

23 and 24 in that paper). The experiments showed that uptake of $\mathrm{NO}_{2}$ and NPN by the denuder walls could be accurately predicted assuming removal is limited only by gas phase diffusion. In Figure 3 we show observations and model predictions of gas penetration from experiments using $\mathrm{NO}_{2}$ and NPN. The diffusivity of $\mathrm{NO}_{2}$ in air is $0.154 \mathrm{~cm}^{2} \mathrm{~s}^{-1}(31)$ and that of NPN was estimated using a hard sphere model and the method of Chapman and Cowling (32) to be $0.070 \mathrm{~cm}^{2} \mathrm{~s}^{-1}$. The largest deviations between the model and data occur at the higher flow rates and short denuder lengths and are likely due to the entrance length required to establish laminar flow, which was not accounted for here but is estimated to be less than $1 \mathrm{~cm}$ at $125 \mathrm{sccm}$. At the lowest flow rates of 255-260 sccm used in the experiments the model and measurements are in excellent agreement. We use the diffusion limited model to calculate the removal efficiency as a function of diffusivity at $125 \mathrm{sccm}$. The bottom panel of Figure 3 shows that at this flow rate even large gas phase molecules are predicted to be removed efficiently.

Once particles leave the denuder they enter the heated quartz tube at $325^{\circ} \mathrm{C}$ where they evaporate. The approximate time required to completely evaporate the particles was calculated using a model which integrates the Hertz-Knudsen equation (Eq. (1)) assuming evaporation and condensation onto spherical particles.

$$
J=\frac{\gamma p}{\sqrt{2 \pi m k_{B} T}}
$$



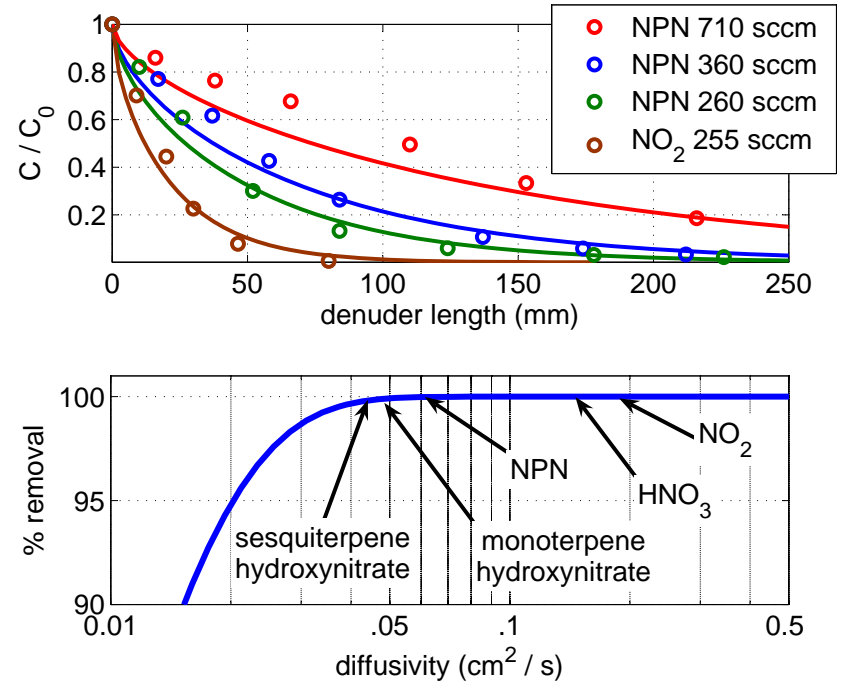

Figure 3: Top: Measured penetration of gas phase $\mathrm{NO}_{2}$ and NPN in the denuder. Bottom: Calculated removal of gas phase nitrates at a flow rate of $125 \mathrm{sccm}$ as a function of diffusivity. $\mathrm{NO}_{\mathrm{y}}$ compounds are noted by their measured $\left(\mathrm{NO}_{2}, \mathrm{HNO}_{3}\right)$ and approximated (others) diffusivities in air.

Here, $J$ is the molecular flux across the particle surface (molecules $\mathrm{cm}^{-2} \mathrm{~s}^{-1}$ ), $\gamma$ is the evaporation coefficient, $p$ is the vapor pressure of the compound (saturation vapor pressure for evaporation $\left(p_{s a t}\right)$ and actual partial pressure in the vapor phase for condensation), $m$ is the molecular mass (g), $k_{B}$ is the Boltzmann constant, and $T$ is the temperature. Details of the particle evaporation calculations are included in the Supporting Information. We calculate that for $\gamma=1$, particles with $C^{*}>10^{-5} \mu \mathrm{g} \mathrm{m}^{-3}$ evaporate in $<10 \mathrm{~ms}$. Complete evaporation of $\alpha$-pinene SOA in the $1.2 \mathrm{~s}$ inlet was verified in one experiment by using an additional heating section with a 2 minute residence time at $150^{\circ} \mathrm{C}$ which is calculated to evaporate particles with $\log _{10} C^{*}$ greater than approximately -7.5. In this experiment no differences in signal were observed between having this additional section held at room temperature or at $150^{\circ} \mathrm{C}$, indicating that particles are completely evaporated in the shorter $325^{\circ} \mathrm{C}$ inlet. 


\section{Particle Transmission Efficiency}

Because semivolatile particles exist in equilibrium with their gas phase precursors, removal of the gas in the denuder might lead to evaporative loss of particles in the system (33). To estimate the importance of this process we used the same model as described here for calculating the evaporation of particles in the heated part of the inlet, this time setting the condensation rate of vapors onto the particles to zero. Figure S2 shows the calculated fraction of particle mass remaining as a function of $C^{*}$ assuming $9.3 \mathrm{~s}$ at $300 \mathrm{~K}$ for 4 initial particle sizes. For this calculation we set the evaporation coefficient to 1 , which is the upper limit of evaporative loss. For $C^{*}<1$ all particle mass is calculated to be transmitted with $>97 \%$ efficiency. At $C^{*}=10,25 \%$ of the mass of the smallest particles is lost, but for particles larger than $100 \mathrm{~nm}$, more than $88 \%$ of mass is transmitted. Significant particle loss may occur for more volatile particles of $C^{*}>100$. However, these more volatile particles are not expected to be an appreciable fraction of the mass in ambient aerosols $(34,35)$, and while particles smaller than $100 \mathrm{~nm}$ may be important by number, in a mass weighted distribution they are also of little importance.

Loss of particles due to diffusion or thermophoresis in the heated part of the inlet are expected to be non-negligible. To determine an upper limit to the loss of particles due to these combined effects we measured the transmission of non-volatile $\mathrm{NaCl}$ particles through the denuder and thermal-dissociation heater sections of the instrument. Details and data from this experiment are provided in the Supporting Information. Significant losses were observed for the smallest particles, while particles with diameters greater than $100 \mathrm{~nm}$ were transmitted with $>85 \%$ efficiency. The transmission efficiency observed with $\mathrm{NaCl}$ is expected to represent a lower limit to the transmission and detection efficiency for semivolatile particles, as semivolatile particles are expected to evaporate and dissociate to $\mathrm{NO}_{2}$ rapidly rather than deposit on the walls of the tube in regions of strong thermal gradients.

The effects of thermophoretic and evaporative loss were combined to evaluate the total penetration of particle mass through the inlet. The results show that the evaporative losses are negligible compared to deposition of particles in the inlet for $C^{*}<1$. At $C^{*}=10$, the difference between 
deposition only and deposition combined with evaporation is largest for particles with diameters between 100 and $200 \mathrm{~nm}$, with a difference of about $10 \%$ of the mass for a $100 \mathrm{~nm}$ particle and about $5 \%$ for a $200 \mathrm{~nm}$ particle. Generally, the depositional losses we observed dominate the total mass loss in all conditions, though as discussed the detection efficiency of semivolatile particles is likely higher than $\mathrm{NaCl}$ particles.

\section{Detection Limit}

The lower limit of detection of the instrument is determined by the ratio of the $\mathrm{NO}_{2} \mathrm{LIF}$ signal relative to the to noise produced from scatter and single photon counting statistics. Using $c$ as the $\mathrm{NO}_{2}$ mixing ratio (ppb), $A$ as the calibration constant (counts $\mathrm{s}^{-1} \mathrm{ppb}^{-1}$ ) and $B$ as the background count rate (counts $\mathrm{s}^{-1}$ ) the signal to noise ratio for some integration time $t$ (s) is given by

$$
\frac{\text { Signal }}{\text { Noise }}=\frac{A c t}{\sqrt{B t+A c t}}
$$

We define the detection limit as the minimum $\mathrm{NO}_{2}$ concentration required for a signal:noise ratio of more than 2. The instrument used in this study had a typical background signal of 675 counts $\mathrm{s}^{-1}$ and a typical calibration constant of 150 counts $\mathrm{s}^{-1} \mathrm{ppb}^{-1}$. These values result in a detection limit of 110 ppt for 10 seconds of averaging, or 45 ppt for one minute. Higher sensitivity $\mathrm{NO}_{2}$ instruments are available and have been employed in other studies $(26,27,29)$. At standard conditions $(1013 \mathrm{hPa}, 300 \mathrm{~K})$ the detection limit for this instrument converts to $0.11 \mu \mathrm{g}-\mathrm{ONO}_{2} \mathrm{~m}^{-3}$ $\min ^{-1}$. It is worth noting that since the instrument is sensitive to the mixing ratio of $\mathrm{NO}_{2}$ produced by the evaporation and thermal dissociation of particles as opposed to the volumetric density, the sensitivity in $\mu \mathrm{g} \mathrm{m}^{-3}$ improves at increased altitude. For example, at $300 \mathrm{hPa}$ the detection limit would be $0.033 \mu \mathrm{g}-\mathrm{ONO}_{2} \mathrm{~m}^{-3} \mathrm{~min}^{-1}$. The total inlet residence time is calculated to be $\approx 10 \mathrm{sec}$ and experiments demonstrated that the instrumental response time to ambient changes was changes was in good agreement with this value. No extended residual signal was observed upon sudden changes such as overflowing the inlet with zero air. Figure 4 shows sample observations with 10 
seconds of signal averaging.

\section{SOA Experiments}

A series of secondary organic aerosol experiments was performed to measure the contribution of organic nitrates to SOA formed under high- $\mathrm{NO}_{\mathrm{x}}$ conditions. Experiments were carried out in a quartz flow tube reactor with an inner diameter of $65 \mathrm{~mm}$. The tube was surrounded by $4, \mathrm{~T} 10$ $\mathrm{Hg}$ vapor lamps, $130 \mathrm{~cm}$ long (UHP, LLC) providing $\approx 12 \mathrm{~mW} \mathrm{~cm}^{-2}$ of $254 \mathrm{~nm}$ light. OH was generated through the photolysis of $\mathrm{H}_{2} \mathrm{O}_{2}$ which was produced by flowing $100 \mathrm{sccm} \mathrm{N}_{2}$ through a mixture of urea hydrogen peroxide (Sigma) and sand which was warmed slightly $\left(30-40^{\circ} \mathrm{C}\right)$. Continuous streams of limonene, $\alpha$-pinene, $\Delta$-3-carene, or tridecane vapors were produced by flowing $1000 \mathrm{sccm} \mathrm{N}_{2}$ over the output of a syringe pump loaded with the respective liquids. The concentrations of the organic compounds added to the flow tube were controlled by varying the pumping rate of the syringe pump, and/or the fraction of the $1000 \mathrm{sccm} \mathrm{N}_{2}$ /organic mixture which was exhausted rather than sent to the flow tube. $10 \mathrm{ppm}$ NO was added at $100 \mathrm{sccm}$ along with $\mathrm{N}_{2}$ and $\mathrm{O}_{2}$ to balance the total flow in the reactor at $2000 \mathrm{sccm}$ and achieve an $\mathrm{O}_{2}$ concentration of $20 \%$ and an NO concentration of $500 \mathrm{ppb}$. Though the concentrations of the organics were typically $<100 \mathrm{ppb}$, the $500 \mathrm{ppb}$ NO concentrations were used to be assured the experiments were high- $\mathrm{NO}_{\mathrm{x}}$. Average $\mathrm{OH}$ concentrations were $\approx 10^{9}$ molecules $\mathrm{cm}^{-3}$ as was verified by measuring the loss rate of hexane. The steady state $\mathrm{HO}_{2}$ produced by $\mathrm{H}_{2} \mathrm{O}_{2}$ photolysis converts a large fraction of the $\mathrm{NO}$ to $\mathrm{NO}_{2}$. The Master Chemical Mechanism (MCM) (36) was used with modified photolysis rates for $254 \mathrm{~nm}$ to calculate that $>90 \%$ of the organic peroxy radicals reacted with NO in the experiments. The MCM simulations were run for $\alpha$-pinene and n-dodecane $\left(\mathrm{C}_{12} \mathrm{H}_{26}\right)$. Detailed reaction mechanisms are not currently available in the MCM for tridecane, limonene or $\Delta$-3-carene. However the tridecane and dodecane mechanisms are expected to be almost identical, and $\alpha$-pinene, limonene and $\Delta$-3-carene have very similar photochemistry $(37,38)$.

A scanning mobility particle sizer (SMPS) system (TSI) was used to measure particle size 


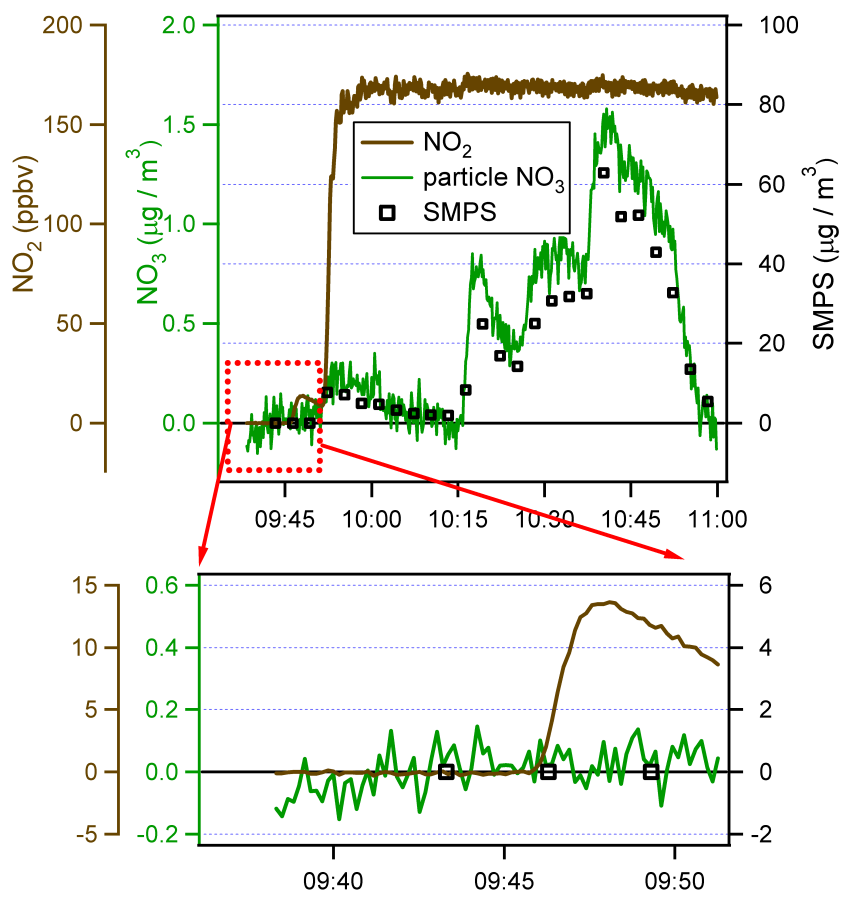

Figure 4: Sample time series from $\Delta$-3-carene experiment. The time series begins sampling air from the irradiated $\mathrm{H}_{2} \mathrm{O}_{2} /$ air mixture. $\mathrm{NO}$ is added just after 9:45, and then at 9:50 more NO is added along with carene. The different aerosol concentrations were achieved by varying the syringe pump flow rate used to deliver the liquid organic material to the air flow stream, and by flowing various amounts of the organic vapor / air mixture into the flow tube vs. to the exhaust. 
distributions. Total particle mass was calculated from the SMPS data assuming a particle density of $1.2 \mathrm{~g} \mathrm{~cm}^{-3}$ which is similar to that reported in a number of studies for high-NO $\mathrm{SOA}_{\mathrm{x}}$ of terpenes (39-44). Particle number distributions were typically centered at $100-150 \mathrm{~nm}$. Figure 4 shows a sample time series of $\mathrm{NO}_{2}$, particle $-\mathrm{ONO}_{2}$ and total aerosol mass from the $\Delta$-3-carene experiment. In this experiment, the organics, $\mathrm{H}_{2} \mathrm{O}_{2}$ and air were initially flowing into the flow tube reactor. Just after 9:45 the NO flow was also added and due to a slight $\mathrm{NO}_{2}$ impurity $12 \mathrm{ppb} \mathrm{NO}_{2}$ was observed. The bottom panel of Figure 4 shows a magnified view of the first 15 minutes of this experiment confirming that $\mathrm{NO}_{2}$ is not an interference for the particle $-\mathrm{ONO}_{2}$ measurement. At 9:51 the lights were turned on, generating $\mathrm{OH}$ and $\mathrm{HO}_{2}$, which produced $\mathrm{SOA}$ and $\mathrm{NO}_{2}$. After 10:00 the concentration of aerosol produced was varied by adding additional the amount of organic precursor to the flow tube at 10:15, 10:25 and 10:37.

Figure 5 shows regression plots of the measured particle $-\mathrm{ONO}_{2}$ vs. total particle mass from the four different organic experiments. In all four experiments the particle $-\mathrm{ONO}_{2}$ and total particle mass were well correlated $\left(\mathrm{R}^{2}>0.94\right)$. The slopes of the linear fits (y-intercepts were held at zero) are the fraction of aerosol mass which is the $-\mathrm{ONO}_{2}$ functional group. The observed $-\mathrm{ONO}_{2}$ content was $6.2 \%$ for $\alpha$-pinene, $8.5 \%$ for $\Delta$-3-carene, $12 \%$ for limonene and $15 \%$ for tridecane. The assumed SOA density used to calculate the total mass from the SMPS data has a direct impact on these calculations. Based on the range of reported values for $\alpha$-pinene SOA (39-44), $1.2 \pm 0.2$ $\mathrm{g} \mathrm{cm}^{-3}$ is the maximum expected range of particle density produced here, resulting in a $\pm 17 \%$ accuracy in the total calculated $\mathrm{OA}$ mass and fractional $-\mathrm{ONO}_{2}$ content.

To estimate the fraction of SOA molecules which are organic nitrates, we make some simple assumptions about the presumed oxidation products of the reactions. The monoterpenes are expected to react with $\mathrm{OH}$ and then $\mathrm{O}_{2}$ to produce hydroxy alkyl peroxy radicals. Under high $\mathrm{NO}_{\mathrm{x}}$ conditions the dominant pathway is for the peroxy radicals to react with NO to form either a hydroxy-nitrate with a molecular weight of 215 , or a hydroxy-alkoxy radical which reacts with $\mathrm{O}_{2}$ to form a hydroxy-carbonyl compound $(\mathrm{MW}=168)(38)$. Analogous assumptions for the tridecane $+\mathrm{OH}$ reaction which is initiated by hydrogen abstraction results in an alkyl nitrate $(\mathrm{MW}=245)$ 

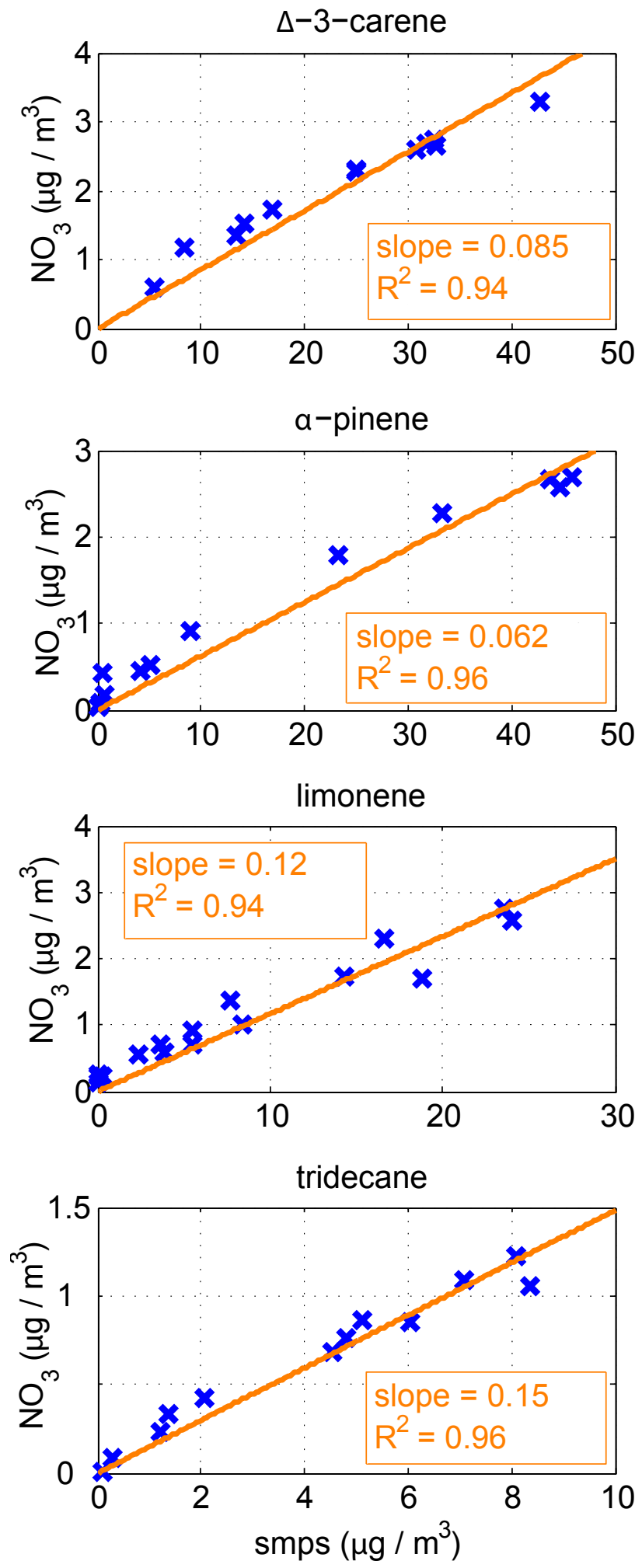

Figure 5: Regressions of particle $\mathrm{NO}_{3}$ and total aerosol mass measurements from the high-NOx photooxidation experiments. 
and a hydroxy-carbonyl $(\mathrm{MW}=215)(45)$. If we assume that the observed $-\mathrm{ONO}_{2}$ content of the aerosol is due to a linear combination of these two types of molecules, we can calculate the fraction of SOA molecules which are hydroxy-nitrates. Under these assumptions we calculate $18 \%$ of the molecules are organic nitrates for $\alpha$-pinene SOA, 25\% for $\Delta$-3-carene, 36\% for limonene and $56 \%$ for tridecane. No doubt the product distribution which contributed to the observed SOA was more complicated than described here, but our analysis relies only on the approximate molecular weights. If for example we assume that all SOA (nitrate and non-nitrate) from the $\alpha$-pinene reaction had a molecular weight of 150 , we calculate $15 \%$ instead of the $18 \%$ for condensed organic nitrates. These values are in agreement with previously reported yields of total organic nitrates from high- $\mathrm{NO}_{\mathrm{x}}$ photooxidation of e.g. $\alpha$-pinene $(18 \pm 9 \%)(46)$. The correspondence between the previously observed and calculated total alkyl nitrate yields, and our calculated contribution of alkyl nitrates to $\mathrm{SOA}$ (i.e. $18 \%$ total $\mathrm{RONO}_{2}(46)$ and $18 \%$ of $\mathrm{SOA}$ is $\mathrm{RONO}_{2}$ ), suggests that the organic nitrate products of high- $\mathrm{NO}_{\mathrm{x}}$ photooxidation are roughly as condensable as the non-nitrate products. To our knowledge, the organic nitrate yields from limonene and $\Delta$-3-carene have not been reported. Total alkyl nitrate yield for the first generation products of tridecane are expected to be $\approx 35 \%$ (10). Lim et al. (13) have studied the SOA formed from high-NO $\mathrm{NO}_{\mathrm{x}}$ photooxidation of a series of n-alkanes and concluded that all observed SOA was organic nitrate.

In summary, we have described and evaluated a new technique which quantifies the total organic nitrate component of aerosols with high time resolution. The technique is sensitive, accurate and specific to organic nitrates. Near unit efficiency was observed for the detection of particles larger than $100 \mathrm{~nm}$. The measurement was used to show that organic nitrates can be a significant contributor to high- $\mathrm{NO}_{\mathrm{x}} \mathrm{SOA}$, with the nitrate group itself being an important contribution to the total aerosol mass. These experiments suggest that in general, the organic nitrate fraction of SOA molecules produced in photooxidation, may be similar to the total yield of $\mathrm{RONO}_{2}$ from the $\mathrm{RO}_{2}$ $+\mathrm{NO}$ reaction, at least for molecules that are $\mathrm{C}_{10}$ or larger. 


\section{Acknowledgement}

The Berkeley authors were supported by NSF ATM-0639847. Part of this work utilized equipment at the Chemical Dynamics Beamline, which is supported by the Director, Office of Energy Research, Office of Basic Energy Sciences, and Chemical Sciences Division of the U.S. Department of Energy under contracts No. DE-AC02-05CH11231

\section{Supporting Information Available}

Additional details of the evaporation model as well as experimental methods and data associated with measuring inlet transmission is included in the Supporting Information. This material is available free of charge via the Internet at http://pubs . acs .org/.

\section{References}

(1) Day, D. A.; Dillon, M. B.; Wooldridge, P. J.; Thornton, J. A.; Rosen, R. S.; Wood, E. C.; Cohen, R. C. On alkyl nitrates, $\mathrm{O}_{3}$, and the "missing $\mathrm{NO}_{y}$ ". J. Geophys. Res. 2003, 108, 4501.

(2) Atlas, E. Evidence for $\geq \mathrm{C}_{3}$ alkyl nitrates in rural and remote atmospheres. Nature 1988, 331, $426-428$.

(3) Measurements of alkyl nitrates in rural and polluted air masses. Atmospheric Environment. Part A. General Topics 1991, 25, 1951 - 1960.

(4) Shepson, P. B.; Anlauf, K. G.; Bottenheim, J. W.; Wiebe, H. A.; Gao, N.; Muthuramu, K.; Mackay, G. I. Alkyl nitrates and their contribution to reactive nitrogen at a rural site in Ontario. Atmospheric Environment. Part A. General Topics 1993, 27, 749 - 757.

(5) Luxenhofer, O.; Schneider, M.; Dambach, M.; Ballschmiter, K. Semivolatile long chain C6C17 alkyl nitrates as trace compounds in air. Chemosphere 1996, 33, 393 - 404. 
(6) Schneider, M.; Luxenhofer, O.; Deissler, A.; Ballschmiter, K. $\mathrm{C}_{1}-\mathrm{C}_{15}$ Alkyl Nitrates, Benzyl Nitrate, and Bifunctional Nitrates: Measurements in California and South Atlantic Air and Global Comparison Using $\mathrm{C}_{2} \mathrm{Cl}_{4}$ and $\mathrm{CHBr}_{3}$ as Marker Molecules. Environ. Sci. Technol. 1998, 32, 3055-3062.

(7) D’Anna, B.; Wisthaler, A.; Andreasen, Ø.; Hansel, A.; Hjorth, J.; Jensen, N. R.; Nielsen, C. J.; Stenstrøm, Y.; Viidanoja, J. Atmospheric Chemistry of $\mathrm{C}_{3}-\mathrm{C}_{6}$ Cycloalkanecarbaldehydes. J. Phys. Chem. A. 2005, 109, $5104-5118$.

(8) Paulot, F.; Crounse, J. D.; Kjaergaard, H. G.; Kroll, J. H.; Seinfeld, J. H.; Wennberg, P. O. Isoprene photooxidation: new insights into the production of acids and organic nitrates. Atmospheric Chemistry and Physics 2009, 9, 1479-1501.

(9) Perring, A. E.; Wisthaler, A.; Graus, M.; Wooldridge, P. J.; Lockwood, A. L.; Mielke, L. H.; Shepson, P. B.; Hansel, A.; Cohen, R. C. A product study of the isoprene+ $+\mathrm{NO}_{3}$ reaction. Atmospheric Chemistry and Physics 2009, 9, 4945-4956.

(10) Day, D. A.; Wooldridge, P. J.; Dillon, M.; Thornton, J. A.; Cohen, R. C. A thermal dissociation laser-induced fluorescence instrument for in situ detection of $\mathrm{NO}_{2}$, peroxy nitrates, alkyl nitrates, and $\mathrm{HNO}_{3}$. J. Geophys. Res. 2002, 107, D6.

(11) Rosen, R. S.; Wood, E. C.; Wooldridge, P. J.; Thornton, J. A.; Day, D. A.; Kuster, W.; Williams, E. J.; Jobson, B. T.; Cohen, R. C. Observations of total alkyl nitrates during Texas Air Quality Study 2000: Implications for O3 and alkyl nitrate photochemistry. J. Geophys. Res. 2004, 109, D07303.

(12) Cleary, P. A.; Murphy, J. G.; Wooldridge, P. J.; Day, D. A.; Millet, D. B.; McKay, M.; Goldstein, A. H.; Cohen, R. C. Observations of total alkyl nitrates within the Sacramento Urban Plume. Atmospheric Chemistry and Physics Discussions 2005, 5, 4801-4843.

(13) Lim, Y. B.; Ziemann, P. J. Products and Mechanism of Secondary Organic Aerosol Formation 
from Reactions of n-Alkanes with $\mathrm{OH}$ Radicals in the Presence of $\mathrm{NO}_{x}$. Environ. Sci. Tech. 2005, 39, $9229-9236$.

(14) Ng, N. L.; Kwan, A. J.; Surratt, J. D.; Chan, A. W. H.; Chhabra, P. S.; Sorooshian, A.; Pye, H. O. T.; Crounse, J. D.; Wennberg, P. O.; Flagan, R. C.; Seinfeld, J. H. Secondary organic aerosol (SOA) formation from reaction of isoprene with nitrate radicals $\left(\mathrm{NO}_{3}\right)$. Atmospheric Chemistry and Physics 2008, 8, 4117-4140.

(15) Rollins, A. W.; Kiendler-Scharr, A.; Fry, J. L.; Brauers, T.; Brown, S. S.; Dorn, H.-P.; Dubé, W. P.; Fuchs, H.; Mensah, A.; Mentel, T. F.; Rohrer, F.; Tillmann, R.; Wegener, R.; Wooldridge, P. J.; Cohen, R. C. Isoprene oxidation by nitrate radical: alkyl nitrate and secondary organic aerosol yields. Atmospheric Chemistry and Physics 2009, 9, 6685-6703.

(16) Bruns, E. A.; Perraud, V.; Zelenyuk, A.; Ezell, M. J.; Johnson, S. N.; Yu, Y.; Imre, D.; Finlayson-Pitts, B. J.; Alexander, M. L. Comparison of FTIR and Particle Mass Spectrometry for the Measurement of Particulate Organic Nitrates. Environ. Sci. Tech. 2010, 44, 1056 1061.

(17) Farmer, D. K.; Matsunga, A.; Docherty, K. S.; Surratt, J. D.; Seinfeld, J. H.; Ziemann, P. J.; Jimenez, J. L. Response of an aerosol mass spectrometer to organonitrates and organosulfates and implications for atmospheric chemistry. Proc. Natl. Acad. Sci. USA 2010, xx, xx.

(18) Rollins, A. W.; Fry, J. L.; Hunter, J. F.; Kroll, J. H.; Worsnop, D. R.; Singaram, S. W.; Cohen, R. C. Elemental analysis of aerosol organic nitrates with electron ionization highresolution mass spectrometry. Atmospheric Measurement Techniques 2010, 3, 301-310.

(19) Jordan, C.; Ziemann, P.; Griffin, R.; Lim, Y.; Atkinson, R.; Arey, J. Modeling SOA formation from $\mathrm{OH}$ reactions with C8-C17 n-alkanes. Atmospheric Environment 2008, 42, 8015 - 8026.

(20) Mylonas, D. T.; Allen, D. T.; Ehrman, S. H.; Pratsinis, S. E. The sources and size distributions of organonitrates in Los Angeles aerosol. Atmospheric Environment. Part A. General Topics 1991, 25, $2855-2861$. 
(21) Allen, D. T.; Palen, E. J.; Haimov, M. I.; Hering, S. V.; Young, J. R. Fourier Transform Infrared Spectroscopy of Aerosol Collected in a Low Pressure Impactor (LPI/FTIR): Method Development and Field Calibration. Aero. Sci. Tech. 1994, 21, 325 - 342.

(22) Garnes, L. A.; Allen, D. T. Size Distributions of Organonitrates in Ambient Aerosol Collected in Houston, Texas. Aero. Sci. Tech. 2002, 36, 983 - 992.

(23) Gómez-González, Y.; Surratt, J. D.; Ceyckens, F.; Szmigielski, R.; Vermeylen, R.; Jaoui, M.; Lewandowski, M.; Offenberg, J. H.; Kleindienst, T. E.; Edney, E. O.; Blockhuys, F.; Alsenoy, C. V.; Maenhaut, W.; Claeys, M. Characterization of organosulfates from the photooxidation of isoprene and unsaturated fatty acids in ambient aerosol using liquid chromatography/(-) electrospray ionization mass spectrometry. J. Mass. Spec. 2008, 43, 371 $-382$.

(24) Surratt, J. D.; Gómez-González, Y.; Chan, A. W. H.; Vermeylen, R.; Shahgholi, M.; Kleindienst, T. E.; Edney, E. O.; Offenberg, J. H.; Lewandowski, M.; Jaoui, M.; Maenhaut, W.; Claeys, M.; Flagan, R. C.; ; Seinfeld, J. H. Organosulfate Formation in Biogenic Secondary Organic Aerosol. J. Phys. Chem. A 2008, 112, 8345 - 8378.

(25) Williams, B. J.; Goldstein, A. H.; Kreisberg, N. M.; Hering, S. V. An in-situ instrument for speciated organic composition of atmospheric aerosols: Thermal desorption aerosol GC/MSFID (TAG). Aero. Sci. Tech. 2006, 40, 627-638.

(26) Thornton, J. A.; Wooldridge, P. J.; Cohen, R. C. Atmospheric $\mathrm{NO}_{2}$ : In Situ laser-Induced Fluorescence Detection at Parts per Trillion Mixing Ratios. Anal. Chem. 2000, 72, 528-539.

(27) Wooldridge, P. J.; Perring, A. E.; Bertram, T. H.; Flocke, F. M.; Roberts, J. M.; Singh, H. B.; Huey, L. G.; Thornton, J. A.; Murphy, J. G.; Fry, J. L.; Rollins, A. W.; LaFranchi, B. W.; Cohen, R. C. Total peroxy nitrates ( $\Sigma \mathrm{PNs}$ ) in the atmosphere: the thermal dissociation-laser induced fluorescence (TD-LIF) technique and comparisons to speciated PAN measurements. Atmospheric Measurement Techniques Discussions 2009, 2, 3055-3097. 
(28) Thornton, J.; Wooldridge, P.; Cohen, R.; Williams, E.; Hereid, D.; Fehsenfeld, F.; J. Stutz, B. A. Comparisons of In situ and Long Path Measurements of $\mathrm{NO}_{2}$ in Urban Plumes. J. Geophys. Res. 2003, 108, 4496.

(29) Fuchs, $\mathrm{H}$. et al. Intercomparison of measurements of $\mathrm{NO}_{2}$ concentrations in the atmosphere simulation chamber SAPHIR during the NO3Comp campaign. Atmospheric Measurement Techniques 2010, 3, 21-37.

(30) Ingham, D. B. Diffusion of Aerosols From a Stream Flowing Through a Cylindrical Tube. Aerosol Science 1975, 6, 125 - 132.

(31) Glasius, M.; Carlsen, M. F.; Hansen, T. S.; Lohse, C. Measurements of nitrogen dioxide on Funen using diffusion tubes. Atmospheric Environment 1999, 33, 1177 - 1185.

(32) Chapman, S.; Cowling, T. G. The mathematical theory of non-uniform gases; an account of the kinetic theory of viscosity, thermal conduction and diffusion in gases; Caimbridge University Press, 1970.

(33) Cappa, C. D. A model of aerosol evaporation kinetics in a thermodenuder. Atmospheric Measurement Techniques Discussions 2009, 2, 2749-2779.

(34) Hallquist, M. et al. The formation, properties and impact of secondary organic aerosol: current and emerging issues. Atmospheric Chemistry and Physics 2009, 9, 5155-5235.

(35) Jimenez, J. L. et al. Evolution of Organic Aerosols in the Atmosphere. Science 2009, 326, $1525-1529$.

(36) Saunders, S. M.; Jenkin, M. E.; Derwent, R. G.; Pilling, M. J. Protocol for the development of the Master Chemical Mechanism, MCM v3 (Part A): tropospheric degradation of nonaromatic volatile organic compounds. Atmospheric Chemistry and Physics 2003, 3, 161-180.

(37) Calvert, J. G.; Atkinson, R.; Kerr, J. A.; Madronich, S.; Moortgat, G. K.; Wallington, T. J.; 
Yarwood, G. The Mechanisms of Atmospheric Oxidation of the Alkenes; Oxford University Press, 2000.

(38) Gas-phase tropospheric chemistry of biogenic volatile organic compounds: a review. Atmospheric Environment 2003, 37, 197 - 219.

(39) Bahreini, R.; Keywood, M.; Ng, N.; Varutbangkul, V.; Gao, S.; Flagan, R.; Seinfeld, J.; Worsnop, D.; Jimenez, J. Measurements of secondary organic aerosol from the oxidation of cycloalkenes, terpenes and m-xylene using an aerodyne mass spectrometer. Environ. Sci. Technol. 2005, 39, $5674-5688$.

(40) Alfarra, M. R.; Paulsen, D.; Gysel, M.; Garforth, A. A.; Dommen, J.; Prévôt, A. S. H.; Worsnop, D. R.; Baltensperger, U.; Coe, H. A mass spectrometric study of secondary organic aerosols formed from the photooxidation of anthropogenic and biogenic precursors in a reaction chamber. Atmospheric Chemistry and Physics 2006, 6, 5279-5293.

(41) Ng, N. L.; Chhabra, P. S.; Chan, A. W. H.; Surratt, J. D.; Kroll, J. H.; Kwan, A. J.; McCabe, D. C.; Wennberg, P. O.; Sorooshian, A.; Murphy, S. M.; Dalleska, N. F.; Flagan, R. C.; Seinfeld, J. H. Effect of $\mathrm{NO}_{x}$ level on secondary organic aerosol (SOA) formation from the photooxidation of terpenes. Atmospheric Chemistry and Physics 2007, 7, 5159-5174.

(42) Offenberg, J. H.; Lewis, C. W.; Lewandowski, M.; Jaoui, M.; Kleindienst, T. E.; Edney, E. O. Contributions of Toluene and $\alpha$-Pinene to SOA Formed in an Irradiated Toluene/ $\alpha$ Pinene/ $\mathrm{NO}_{\mathrm{x}} /$ Air Mixture: Comparison of Results Using ${ }^{14} \mathrm{C}$ Content and SOA Organic Tracer Methods. Environ. Sci. Technol. 2007, 41, 3972 - 3976.

(43) Yu, Y.; Ezell, M. J.; Zelenyuk, A.; Imre, D.; Alexander, L.; Ortega, J.; D’Anna, B.; Harmon, C. W.; Johnson, S. N.; Finlayson-Pitts, B. J. Photooxidation of $\alpha$-pinene at high relative humidity in the presence of increasing concentrations of $\mathrm{NO}_{\mathrm{x}}$. Atmospheric Environment 2008, $42,5044-5060$. 
(44) Zelenyuk, A.; Yang, J.; Song, C.; Zaveri, R.; Imre, D. A New Real-Time Method for Determining Particles' Sphericity and Density: Application to Secondary Organic Aerosol Formed by Ozonolysis of $\alpha$-Pinene. Environ. Sci. Technol. 2008, 42, $8803-8038$.

(45) Atmospheric chemistry of alkanes: Review and recent developments. Atmospheric Environment 2008, 42, 5859 - 5871 .

(46) Noziére, B.; Barnes, I.; Becker, K.-H. Product study and mechanisms of the reactions of $\alpha$ pinene and of pinonaldehyde with OH radicals. J. Geophys. Res. 1999, 104, $23645-23656$. 


\section{LEGAL DISCLAIMER}

This document was prepared as an account of work sponsored by the United States Government. While this document is believed to contain correct information, neither the United States Government nor any agency thereof, nor The Regents of the University of California, nor any of their employees, makes any warranty, express or implied, or assumes any legal responsibility for the accuracy, completeness, or usefulness of any information, apparatus, product, or process disclosed, or represents that its use would not infringe privately owned rights. Reference herein to any specific commercial product, process, or service by its trade name, trademark, manufacturer, or otherwise, does not necessarily constitute or imply its endorsement, recommendation, or favoring by the United States Government or any agency thereof, or The Regents of the University of California. The views and opinions of authors expressed herein do not necessarily state or reflect those of the United States Government or any agency thereof or The Regents of the University of California. 